\title{
The Viability of Converting Diesel Powered Automobiles to Use Compressed Natural Gas as Fuel in Nigeria
}

\author{
Anyadiegwu C. I. C. ${ }^{1}$, Ohia N. P. ${ }^{2}$, Muonagor C. M. ${ }^{3}$ \\ ${ }^{1}$ Department of Petroleum Engineering, Federal University of Technology, Owerri \\ ${ }^{2}$ Department of Petroleum Engineering, Federal University of Technology, Owerri \\ ${ }^{3}$ Institute of Petroleum Studies, Port Harcourt, in affiliation with Institut Francais du Petrole (IFP), \\ France
}

\begin{abstract}
The data for costs of constructing and running CNG-powered vehicles were obtained for the study. Economic analyses of running the CNG-powered vehicles and that of running diesel vehicles were performed. The initial costs of project and operating costs amounted to N3.71million, N1.31million for CNG, and N3.22million, N2.67million for diesel respectively. This difference in the capital costs is basically due to the addition of the extra parts and connections to convert the diesel-powered vehicle to a bi-fuel-powered vehicle to enable the use of CNG as fuel. The difference in the operating costs revealed that the costs of the two fuels are not the same. The net revenue for CNG is N2.55 million while that for diesel is N1.2 million. This difference in net revenues resulted from the difference in their gross revenues and/or in operating costs. Figures were used to determine the pay-out of the projects which is 1.45 years for CNG and 2.7 years for diesel respectively. The Net Present Value (NPV) and other parameters that make up the project economics were estimated for CNG and diesel. The NPV for CNG at an expected rate of return of $10 \%$ is N15.7 million while for diesel, the NPV is N5.86 million. The summary of the result of the calculations of all the parameters examined for both CNG and diesel was also presented. From the whole analysis done it is easily seen that using CNG for powering vehicles is more profitable than using diesel.
\end{abstract}

Keywords: Compressed natural gas, diesel, economic analysis, NPV, pay-out, IRR, automobiles.

\section{INTRODUCTION}

Natural gas, a fossil fuel comprised mostly of methane, is one of the cleanest burning alternative fuels (US DOE, 2013).

Increasing demand for natural gas in power plants will require new supplies from non-North American countries, increasing dependence on foreign sources of energy. The Energy Information Administration (EIA) predicts that, by 2025, more than 15 percent of USA natural gas supplies will be imported from countries other than Canada and Mexico. Fig 1.1 below shows the consumption of natural gas for vehicles in the US between 1996 and 2005.

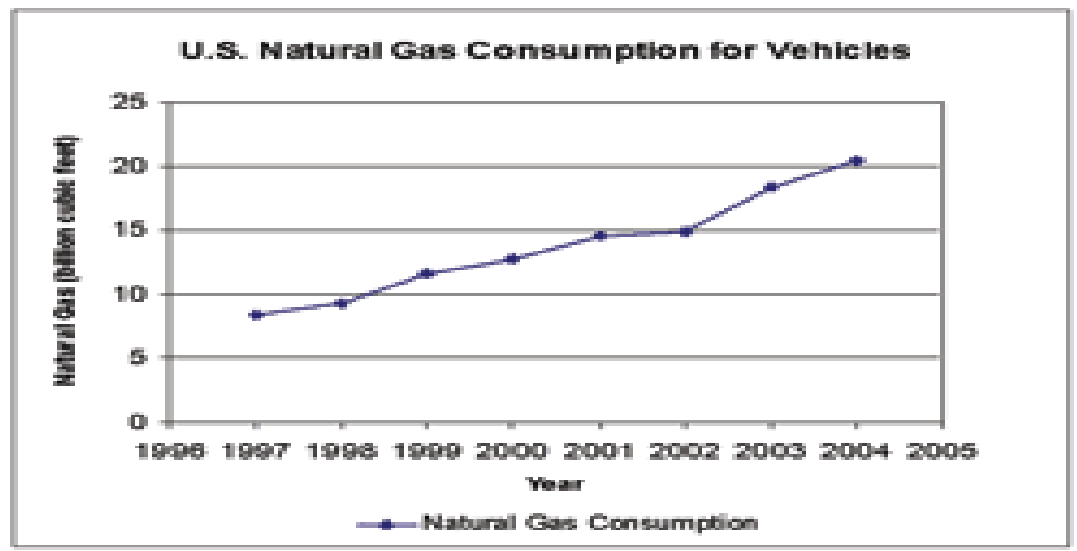

Fig1.1. US Natural Gas Consumption for Vehicles from 1996 to 2005

Source: CEC, (2013). 
The Viability of Converting Diesel Powered Automobiles to Use Compressed Natural Gas as Fuel in Nigeria

Natural gas can be used in the form of compressed natural gas (CNG) or liquefied natural gas (LNG) to fuel cars and trucks.

Dedicated natural gas vehicles are designed to run on natural gas only, while dual-fuel or bi-fuel vehicles can also run on gasoline or diesel. Dual-fuel vehicles allow users to take advantage of the wide-spread availability of gasoline or diesel but use a cleaner, more economical alternative when natural gas is available. Since natural gas is stored in high-pressure fuel tanks, dual-fuel vehicles require two separate fueling systems, which take up passenger/cargo space.

Natural gas vehicles are not available on a large scale in our present era - only a few models are currently offered for sale. However, conventional gasoline and diesel vehicles can be retrofitted for CNG (CEC, 2013).

The fact that natural gas is combustible and burns more cleanly than some other energy sources helps reinforce its position as one of the most highly used energy sources. Energy yielded by natural gas can be measured in a variety of ways, and the most common is the Gigajoule (GJ), which is one billion joules, the metric measure for heat or energy (Go Natural Gas Inc., 2009).

According to US DOE, (2013), some of the advantages of Natural Gas are that: it produces roughly $20 \%$ to $45 \%$ less smog pollutants than other fuels; it emits about 5\% to $9 \%$ less greenhouse gas than other fuels; it is also cheap compared to other fuels like gasoline.

Its main disadvantages are that it has limited vehicle availability and it is less readily available than gasoline and diesel.

\section{Methodology}

\subsection{Converting Petrol/Diesel-Powered Vehicles to Cng-Powered Vehicles}

This conversion involves installing extra parts into the diesel-powered vehicles that would make them bi-fuel powered vehicles. This means that they would be able to be both powered by diesel and CNG.

The flow chart for the extra components and their connection sequence for the conversion of dieselpowered vehicles to CNG-powered vehicles are shown in Fig 2.1 below:

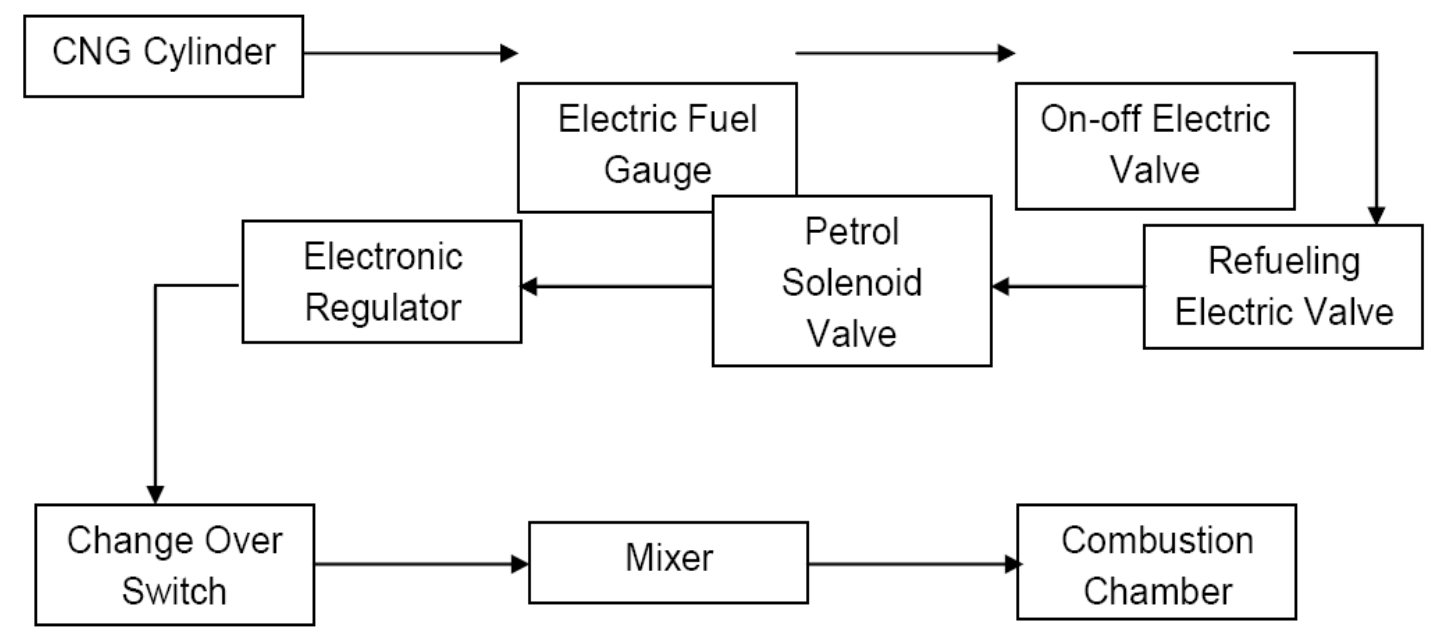

Fig2.1. Flow Chart of the Installations for Converting Diesel Vehicles to CNG-powered

\subsection{Output of Cng-Powered Vehicles}

\subsubsection{Heating Values}

The heating value of CNG is $1518533 \mathrm{KJ} / \mathrm{scf}$ and the heating value of diesel with density of 0.832 $\mathrm{Kg} / \mathrm{l}$ is $37273.6 \mathrm{KJ} / \mathrm{l}$ (The Engineering Toolbox, 2013).

\subsection{Evaluation of the Economic Viability of Using Cng-Powered Vehicles}

The economic flow chart for running vehicles with CNG consists of the various costs at different stages: costs of putting the extra parts of the CNG-powered vehicle together, which are summed up to get the total capital cost as shown in Fig 3.2 below. 


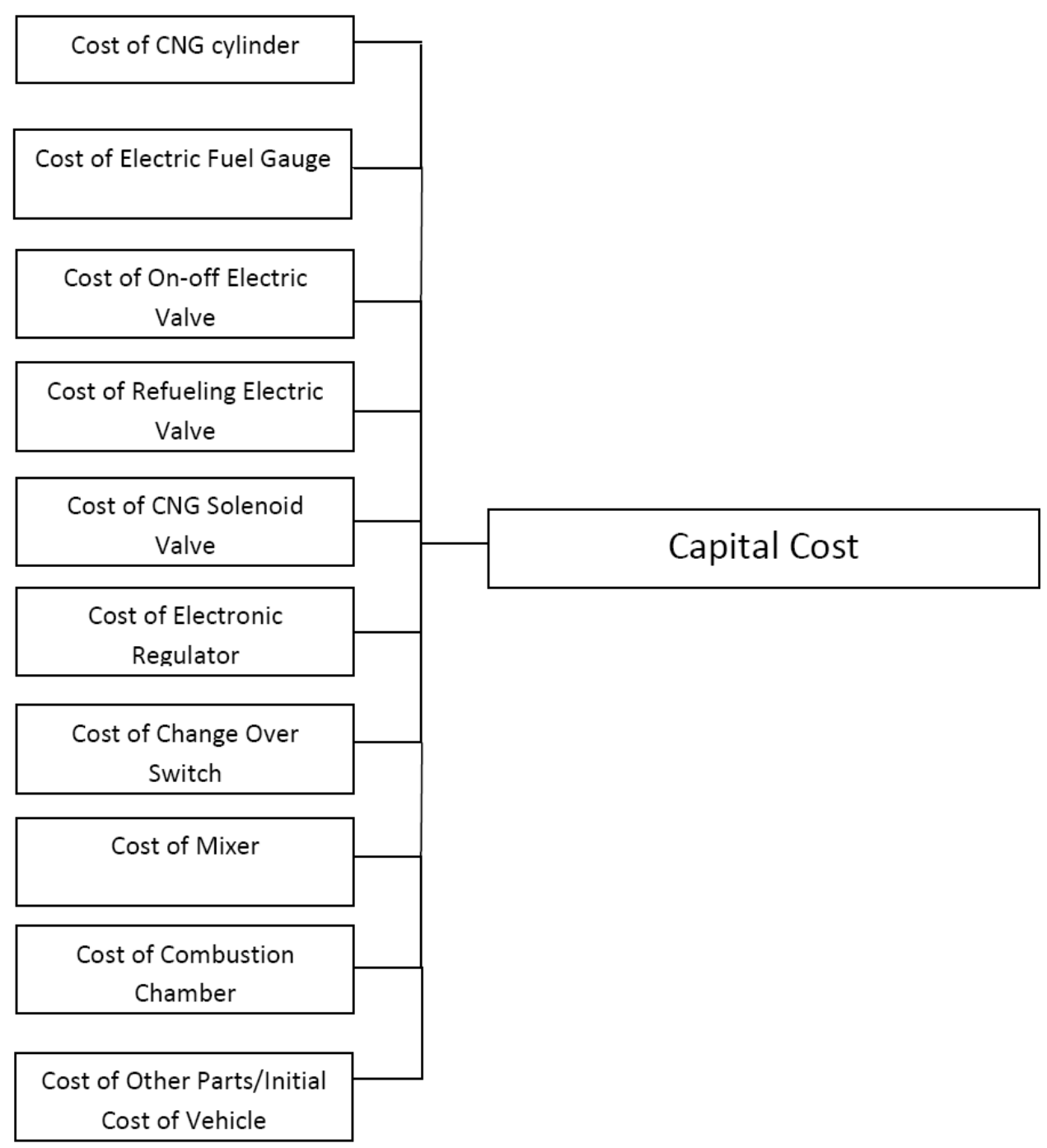

Fig2.2. Economic flow chart for manufacturing CNG-powered vehicles

\section{Costs Analysis}

As in all infrastructural investments in the energy sector, manufacturing CNG-powered vehicles is capital intensive. Investors usually use the return on investment as an indicator for the viability of such projects. It has been estimated that investors require a rate of return of $12 \%$ to $15 \%$ for regulated projects, and close to $20 \%$ for unregulated projects. The higher expected return from unregulated projects is due to the higher perceived market risk. In addition significant expenses are accumulated during the planning and location of potential storage sites to determine its suitability, which further increases the risk (American Gas Association, 1997).

The capital expenditure to manufacture the vehicle in Nigeria depends on the separate costs of the extra parts required to make the diesel-powered vehicles bi-fuel-powered vehicles.

The conversion rate of naira to dollar as at April, 2014 is given as:

$\$ 1=\mathrm{N} 161$

Several items contribute to the total investment necessary to put CNG-powered vehicle into operation, as demonstrated in Fig 2.2. They include:

i. Cost of CNG Cylinder: The CNG cylinder is meant for storing CNG in the vehicle for use. CNG cylinders are manufactured from a special steel alloy and are seamless in construction. Their compact size allows them to easily fit into a small car. An empty CNG cylinder with a 50 liter-water-carrying capacity weighs $48 \mathrm{~kg}$ (approximately), and has a length of $835 \mathrm{~mm}$ and a diameter of $316 \mathrm{~mm}$. The 50 liter capacity cylinder is the one most regularly used in CNG kits but cylinders with 45 liter, 55 liter, 60 liter and 65 liter capacity are used as well. 
A cylinder with a 50 liter water-carrying capacity is capable of carrying approximately $9 \mathrm{~kg}$ of CNG. This is equivalent to 12.5 liters of petrol and will allow a run of about 150-160 km for a medium sized $1300 \mathrm{CC}$ car. An electronic fuel gauge fitted on the dashboard which is part of the conversion kit indicates the quantity of $\mathrm{CNG}$ left in the cylinder.

CNG cylinders are designed and built to withstand high pressure. The maximum pressure in a CNG cylinder is up to 200 bar. CNG cylinders are safe as they are manufactured as per specific requirements and tested before use, in accordance with international specifications and standards, and are duly approved by the Chief Controller of Explosives $(\mathrm{CCoE})$. Moreover, they are provided with a pressure relief device (PRD) that consists of a fusible plug and a burst disc that ruptures in case of extremely high pressure and temperature.

On an average, vehicle owners lose about one third of their boot space when their car is converted to use CNG. The boot space also depends upon the size of vehicle and cylinder make. However people who wish to convert to CNG can still install carriers on their vehicles to compensate for the lost boot space (Mahanagar Gas Limited, 2013).

ii. Cost of Electric Fuel Gauge: The electric fuel gauge is installed to check the level of CNG in the $\mathrm{CNG}$ cylinder and as such to show whether there is an enough fuel for an impending journey with the vehicle.

iii. Cost of On-Off Electric Valve: The electric on-off control valve is a hydraulically operated sleeve type valve with an electric solenoid control. The flow through the valve is controlled by a rubber sleeve which is actuated by hydraulic pressure. The valve is either in the fully opened or the closed (shut off) position when operated electrically. When the selector is pointed to the "AUTO" position then the electric solenoid is used to automatically open or close the valve. The 3-way electric solenoid must be energized to open the valve and de-energized to close the valve. Pointing the manual selector handle to "OPEN" or "CLOSE" will override the "AUTO" control. The manual selector can be used to hold the valve partly open by opening the valve part way and then pointing the selector handle midway between "OPEN" and "CLOSE" (Nelson Irrigation, 2013).

iv. Cost of Re-fuelling Electric Valve: This is a valve for dispensing natural gas. The valve itself functions as an internally piloted valve with a pilot orifice in the piston, which is one of the most important components of the valve. In order to withstand the high pressure, the piston is produced from a single piece of special plastic. Specially designed solenoid valves are required to control the flow of the CNG.

v. Cost of CNG Solenoid Valve: A solenoid valve is an electromechanically operated valve. The valve is controlled by an electric current through a solenoid: in the case of a two-port valve the flow is switched on or off; in the case of a three-port valve, the outflow is switched between the two outlet ports. Multiple solenoid valves can be placed together on a manifold.

Solenoid valves are the most frequently used control elements in fluidics. Their tasks are to shut off, release, dose, distribute or mix fluids. They are found in many application areas. Solenoids offer fast and safe switching, high reliability, long service life, good medium compatibility of the materials used, low control power and compact design.

vi. Cost of Electronic Regulator: Electronic fuel pressure regulator works directly with line of CNG pumps to reduce heat build-up and vapor lock conditions related to the operation.

vii. Cost of Change Over Switch: Change Over Switch is electronic control unit for interchange refinery fuel and gas of $\mathrm{CNG}$ injection cars. It is meant for switching from refinery fuel sucking to CNG sucking and vice versa.

viii. Cost of Mixer: This is a gas mixer for blending CNG and other additives required for its use in running vehicles. Conventional gas mixers have remained essentially unchanged for the past 40 years, based on proportional gas mix controlled manually and the need to increase the size of the mixer if a greater capacity is necessary. Furthermore, different gas mixtures often require different mixers to be used.

ix. Cost of Combustion Chamber: This is the unit where the CNG fuel burns to yield the amount of energy expended in the course of running the vehicle. 
$\mathrm{x}$. Cost of Other Parts: This is the cost of putting other parts and the required body parts of the vehicle in place. This may also be referred to as the initial cost of the diesel-powered vehicle before it is converted to a bi-fuel-powered vehicle.

The total capital cost is given as the sum of the costs $\mathrm{i}$ to $\mathrm{x}$.

Annual Operating cost $=$ Fuel cost + Maintenance cost

Gross Revenue $=$ Revenue per $\mathrm{km}$ moved $* \mathrm{Km}$ covered by the vehicle running on the available volume of $\mathrm{CNG}$

Net revenue for subsequent years of operation $=$

Gross revenue - Annual Operating cost

\section{RESUlT}

The heating values and prices of CNG and diesel are as shown in Table 3.1 below:

Table3.1. Heating Values and Prices of CNG and Diesel

\begin{tabular}{|c|c|c|}
\hline Fuel & CNG & Diesel \\
\hline Heating Value & $1518533 \mathrm{KJ} / \mathrm{scf}$ & $37273.6 \mathrm{KJ} / \mathrm{l}$ \\
\hline Price & $\$ 0.38 / 1$ & $\$ 0.50 / 1$ \\
\hline
\end{tabular}

Source: The Engineering Toolbox, (2013)

\subsection{Economic Analysis of CNG-Powered Vehicle}

3.1.1. Costs Analyses for CNG-powered Vehicle

3.1.1.1. Total Capital Cost, (C)

\subsection{Initial Cost of Vehicle, (I)}

The cost of procuring a diesel-powered vehicle is $\$ 20000=\mathrm{N} 3.2$ million

\subsection{Cost of Installing the $C N G$ Cylinder, $\left(C_{C N G}\right)$}

The cost of installing the CNG cylinder and its accessories is $\$ 280=\mathrm{N} 45080$

3.1.1.1.3. Cost of Electric Fuel Gauge, (EFG)

The installation of electric fuel gauge is set at $\$ 59.38=\mathrm{N} 9560$

\subsection{Cost of On-off Electric Valve, (OEV)}

The cost of buying and installing the on-off electric valve is $\$ 1000=\mathrm{N} 161000$

\subsection{Cost of the Re-fuelling Electric Valve, (RE)}

The cost of installing the re-fuelling valve is $\$ 800=\mathrm{N} 128800$

3.1.1.1.6. Cost of CNG Solenoid Valve, (SVCNG)

The installation of the CNG solenoid valve is set at $\$ 500=\mathrm{N} 80500$

\subsection{Cost of the Electronic Regulator, (ER)}

The cost of buying and installing electronic regulator is $\$ 100=\mathrm{N} 16100$

\subsection{Cost of Installing Fuel Change Over Switch, $\left(\operatorname{COS}_{C N G}\right)$}

The cost of installing the fuel change over switch is $\$ 200=$ N32200

3.1.1.1.9. Cost of Installing Fuel Mixer, $\left(M_{C N G}\right)$

The installation of fuel mixer is set at $\$ 10=\mathrm{N} 1610$

\subsection{Cost of Installing Combustion Chamber, (CC)}

The cost of installing the combustion chamber and Valve is $\$ 1000=\mathrm{N} 161000$

Total Capital Cost $(\mathrm{C})=\mathrm{I}+\mathrm{C}_{\mathrm{CNG}}+\mathrm{EFG}+\mathrm{OEV}+\mathrm{RE}+\mathrm{SV}_{\mathrm{CNG}}+\mathrm{ER}+\mathrm{COS}_{\mathrm{CNG}}+\mathrm{M}_{\mathrm{CNG}}+\mathrm{CC}$

Total Capital Cost $(C)=\$ 23049.38=$ N3.71 million 
The Viability of Converting Diesel Powered Automobiles to Use Compressed Natural Gas as Fuel in Nigeria

\subsubsection{Annual Cost, (A)}

\subsection{Fuel Cost, $(F c)$}

According to Watt (2000), the average kilometer per liter covered by a vehicle running on CNG is $1.66 \mathrm{~km} / 1$. A vehicle that plies $93 \mathrm{~km}$ to and fro within south-east, Nigeria would be covering a distance of $186 \mathrm{~km}$. If 11 of $\mathrm{CNG}$ can cover a distance of $1.66 \mathrm{~km}$ then to cover a distance of $186 \mathrm{~km}$ the volume of CNG that would be required is 1121 . Since the cost of CNG is $\$ 0.38 / 1$, then the cost of 1121 of CNG is $\$ 42.6$. If the vehicle travels that $93 \mathrm{~km}$ and back 15 times in a month it means that the cost of CNG for the 15 trips in a month is $\$ 638.7$. Then the annual cost of fuel would be $\$ 638.7 * 12=\$ 7664=$ N1.23 million

\subsection{Maintenance Cost, (Mc)}

The cost of maintaining the vehicle, servicing the engine and other parts and repairing the damaged parts would amount to about $\$ 40$ per month which is $\$ 480$ ie N77280 annually.

Annual Cost, $\mathrm{A}=\mathrm{F}_{\mathrm{c}}+\mathrm{M}_{\mathrm{c}}=\$ 7664+\$ 480=\$ 8144=\mathrm{N} 1.31$ million

\subsubsection{Revenue Analyses for CNG-powered Vehicles}

If the revenue the vehicle earns for one trip of $93 \mathrm{~km}$ and back is $\$ 133$, then Gross Revenue $=\$ 133 *$ $15 * 12=\$ 24000$.

Annual Net Revenue $=\$ 24000-\$ 8144=\$ 15856=\mathrm{N} 2.38$ million

\subsubsection{NPV and IRR for the CNG-powered Vehicle Project}

Net Present Value, (NPV) is a measure of profitability of any project. The net present value of a time series of cash flows, both incoming and outgoing, is the sum of the present values (PVs) of the individual cash flows.

NPV compares the value of 1 dollar today to its value in future, taking inflation and returns into consideration. If the NPV of a prospective project is positive, it is accepted. However, if NPV is negative, the project should be discouraged because cash flows will also be negative (Wikimedia, 2013)

The cash flows in dollars for the CNG-powered vehicle project over the space of 15 years is shown in Table 3.2 and also the cash flows in millions of Naira for the CNG-powered vehicle project over the space of 15 years is shown in Table 3.3:

Table3.2. Cash Flows for the CNG Vehicle Project over the space of 15 years

\begin{tabular}{|l|l|l|l|l|l|l|l|}
\hline Time (yr) & CAPEX $\mathbf{( \$ )}$ & OPEX $\mathbf{( \$ )}$ & GROSS REV $\mathbf{( \$ )}$ & NCR (\$) & CUM NCR (\$) & PV @ 5\% (\$) & PV @ 10\% (\$) \\
\hline 0 & 23049 & 0 & 0 & $23049)$ & $(23049)$ & $(23049)$ & $(23049)$ \\
\hline 1 & 0 & 8144 & 24000 & 15856 & $(7193)$ & 15101 & 14415 \\
\hline 2 & 0 & 8144 & 24000 & 15856 & 8663 & 14382 & 13104 \\
\hline 3 & 0 & 8144 & 24000 & 15856 & 24519 & 13697 & 11913 \\
\hline 4 & 0 & 8144 & 24000 & 15856 & 40375 & 13045 & 10830 \\
\hline 5 & 0 & 8144 & 24000 & 15856 & 56231 & 12424 & 9845 \\
\hline 6 & 0 & 8144 & 24000 & 15856 & 72087 & 11832 & 8950 \\
\hline 7 & 0 & 8144 & 24000 & 15856 & 87943 & 11269 & 8137 \\
\hline 8 & 0 & 8144 & 24000 & 15856 & 103799 & 10732 & 7397 \\
\hline 9 & 0 & 8144 & 24000 & 15856 & 119655 & 10221 & 6724 \\
\hline 10 & 0 & 8144 & 24000 & 15856 & 135511 & 9734 & 6113 \\
\hline 11 & 0 & 8144 & 24000 & 15856 & 151367 & 9271 & 5557 \\
\hline 12 & 0 & 8144 & 24000 & 15856 & 167223 & 8829 & 5052 \\
\hline 13 & 0 & 8144 & 24000 & 15856 & 183079 & 8409 & 4593 \\
\hline 14 & 0 & 8144 & 24000 & 15856 & 198935 & 8008 & 4175 \\
\hline 15 & 0 & 8144 & 24000 & 15856 & 214791 & 7627 & 3796 \\
\hline
\end{tabular}


Anyadiegwu C. I. C. et al.

Table3.3. Cash Flows in millions of Naira for the CNG-powered Vehicle Project over the space of 15 years

\begin{tabular}{|l|l|l|l|l|l|l|l|}
\hline $\begin{array}{c}\text { Time } \\
(\mathbf{y r})\end{array}$ & $\begin{array}{c}\text { CAPEX } \\
(\mathbf{N M})\end{array}$ & $\begin{array}{c}\text { OPEX } \\
(\mathbf{N M})\end{array}$ & $\begin{array}{c}\text { GROSS REV } \\
(\mathbf{N M})\end{array}$ & $\begin{array}{c}\text { NCR } \\
(\mathbf{N M})\end{array}$ & $\begin{array}{c}\text { CUMNCR } \\
(\mathbf{N M})\end{array}$ & \multicolumn{1}{|c|}{$\begin{array}{c}\text { PV @ 5\% } \\
(\mathbf{N M})\end{array}$} & $\begin{array}{c}\text { PV @ 10\% } \\
(\mathbf{N M})\end{array}$ \\
\hline 0 & 3.71 & 0.00 & 0.00 & $(3.71)$ & $(3.71)$ & $(3.71)$ & $(3.71)$ \\
\hline 1 & 0.00 & 1.31 & 3.86 & 2.55 & $(1.16)$ & 2.43 & 2.32 \\
\hline 2 & 0.00 & 1.31 & 3.86 & 2.55 & 1.39 & 2.32 & 2.11 \\
\hline 3 & 0.00 & 1.31 & 3.86 & 2.55 & 3.95 & 2.21 & 1.92 \\
\hline 4 & 0.00 & 1.31 & 3.86 & 2.55 & 6.50 & 2.10 & 1.74 \\
\hline 5 & 0.00 & 1.31 & 3.86 & 2.55 & 9.05 & 2.00 & 1.59 \\
\hline 6 & 0.00 & 1.31 & 3.86 & 2.55 & 11.61 & 1.90 & 1.44 \\
\hline 7 & 0.00 & 1.31 & 3.86 & 2.55 & 14.16 & 1.81 & 1.31 \\
\hline 8 & 0.00 & 1.31 & 3.86 & 2.55 & 16.71 & 1.73 & 1.19 \\
\hline 9 & 0.00 & 1.31 & 3.86 & 2.55 & 19.26 & 1.65 & 1.08 \\
\hline 10 & 0.00 & 1.31 & 3.86 & 2.55 & 21.82 & 1.57 & 0.98 \\
\hline 11 & 0.00 & 1.31 & 3.86 & 2.55 & 24.37 & 1.49 & 0.89 \\
\hline 12 & 0.00 & 1.31 & 3.86 & 2.55 & 26.92 & 1.42 & 0.81 \\
\hline 13 & 0.00 & 1.31 & 3.86 & 2.55 & 29.48 & 1.35 & 0.74 \\
\hline 14 & 0.00 & 1.31 & 3.86 & 2.55 & 32.03 & 1.29 & 0.67 \\
\hline 15 & 0.00 & 1.31 & 3.86 & 2.55 & 34.58 & 1.23 & 0.61 \\
\hline
\end{tabular}

From Table 3.2, the Net Present Value at an expected rate of return/discount rate (the rate which the capital needed for the project could return if invested in an alternative venture) of 5\% is the sum of the present values in that column for 5\%. The sum of the PVs at 5\% is $\$ 141531=\mathrm{N} 22.79$ million

The NPV at a discount rate of $10 \%=\$ 97553=$ N15.71 million

The project is worth investing on since the NPV in both cases is greater than zero.

The internal rate of return (IRR) on investment of a project is the rate of return that makes the net present value of all cash flows from a particular investment equal to zero. The higher the IRR of a project, the more desirable it is to undertake the project. Table 3.3 is another table generated from Table 3.2 and it shows the cash flows for the project over 2 years. The essence of Table 3.4 is for the generation of the IRR of the project which has to be computed using very short times of undertaking the project. For more accurate values and for taking extreme cases, few number of years, like 2 to 4 years, is applied in generating the IRR rather than many number of years. Table 3.4 is shown below:

Table3.4. Cash Flows for the CNG Vehicle Project over the space of 2 years

\begin{tabular}{|l|l|l|l|l|l|l|l|}
\hline Time (yr) & CAPEX (\$) & OPEX (\$) & GROSS REV (\$) & NCR (\$) & CUM NCR (\$) & PV @ 5\% (\$) & PV @ 10\% (\$) \\
\hline 0 & 23049 & 0 & 0 & $(23049)$ & $(23049)$ & $(23049)$ & $(23049)$ \\
\hline 1 & 0 & 8144 & 24000 & 15856 & $(7193)$ & 15101 & 14415 \\
\hline 2 & 0 & 8144 & 24000 & 15856 & 8663 & 14382 & 13104 \\
\hline
\end{tabular}

Table 3.5 is a table of the net present values for the CNG-powered vehicle project at various discount rates, which was used in generating a plot of NPV against discount rate as shown in Fig 3.1 for the determination of the IRR which is $24 \%$. The $24 \%$ is the discount rate at which the NPV equals zero.

Table3.5. NPV at various Discount Rates

\begin{tabular}{|l|l|}
\hline Discount Rate (\%) & NPV (\$) \\
\hline 5 & 6433.812 \\
\hline 10 & 4469.678 \\
\hline 15 & 2728.24 \\
\hline 20 & 1175.444 \\
\hline 25 & $(216.36)$ \\
\hline 30 & $(1469.83)$ \\
\hline 35 & $(2603.68)$ \\
\hline 40 & $(3633.49)$ \\
\hline
\end{tabular}


The Viability of Converting Diesel Powered Automobiles to Use Compressed Natural Gas as Fuel in Nigeria

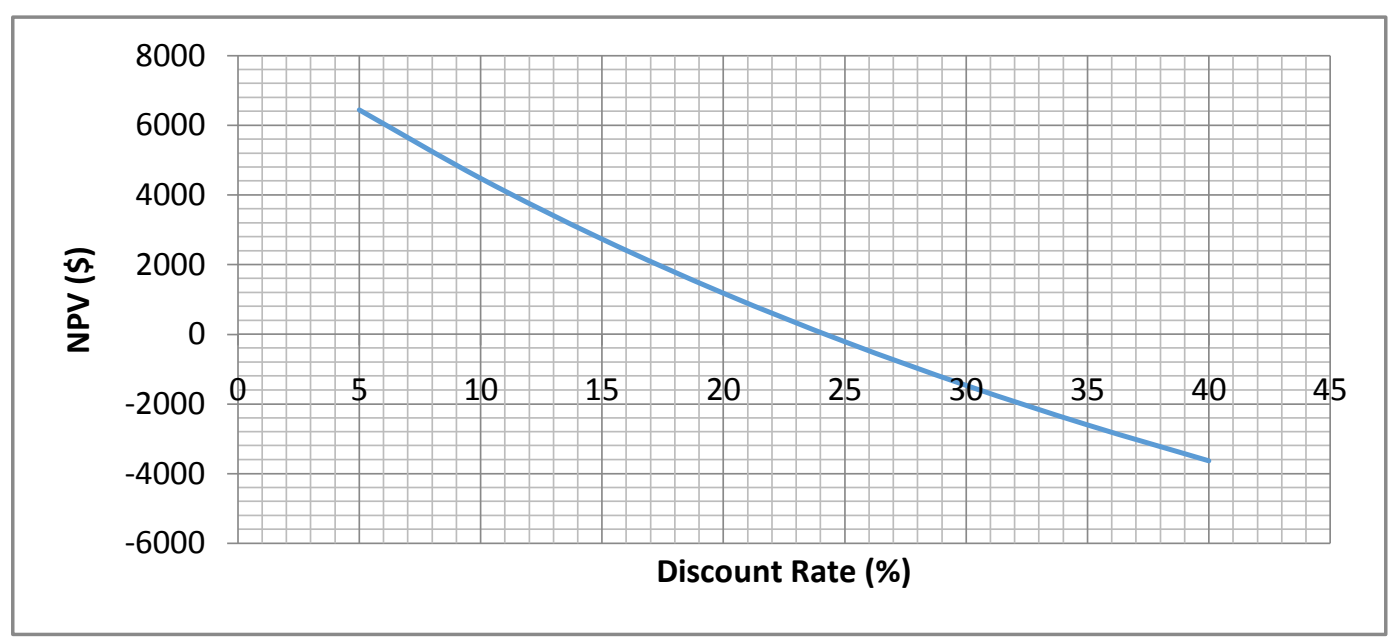

Fig3.1. Plot of NPV against Discount Rate

\subsubsection{Pay-out (PO) for the CNG-powered Vehicle Project}

The pay-out for a project refers to the time (years) at which the initial investment on the project is just recovered. It is the time at which cumulative NCR becomes zero.

Table 3.6 shows the cumulative NCR and NCR after 7 years while Fig 3.2 represents the graph of time against cumulative NCR in billions of dollars for the CNG-powered vehicle project.

Table3.6: Cum NCR after 7 years

\begin{tabular}{|l|l|l|}
\hline Time (yr) & NCR $(\mathbf{\$})$ & CUM NCR (\$) \\
\hline 0 & $(23049)$ & $(23049)$ \\
\hline 1 & 15856 & $(7193)$ \\
\hline 2 & 15856 & 8663 \\
\hline 3 & 15856 & 24519 \\
\hline 4 & 15856 & 40375 \\
\hline 5 & 15856 & 56231 \\
\hline 6 & 15856 & 72087 \\
\hline 7 & 15856 & 87943 \\
\hline
\end{tabular}

From Fig 3.2, cumulative NCR becomes zero between the 1st and 2nd year. In this research work, 1 and 2 years were used as the initial point (IP) and final point, (FP) respectively.

Applying interpolation:

$(\mathrm{PO}-\mathrm{IP}) /(\mathrm{FP}-\mathrm{IP})=(0-\mathrm{CUM}$ NCR at IP $) /(\mathrm{CUM}$ NCR at FP $-\mathrm{CUM}$ NCR at IP $)$

$(\mathrm{PO}-1 \mathrm{yr}) /(2 \mathrm{yrs}-1 \mathrm{yr})=(0-(-7193)) /(8663-(-7193))$

$\mathrm{PO}=1.45 \mathrm{yrs}$ as indicated in Fig. 3.2.

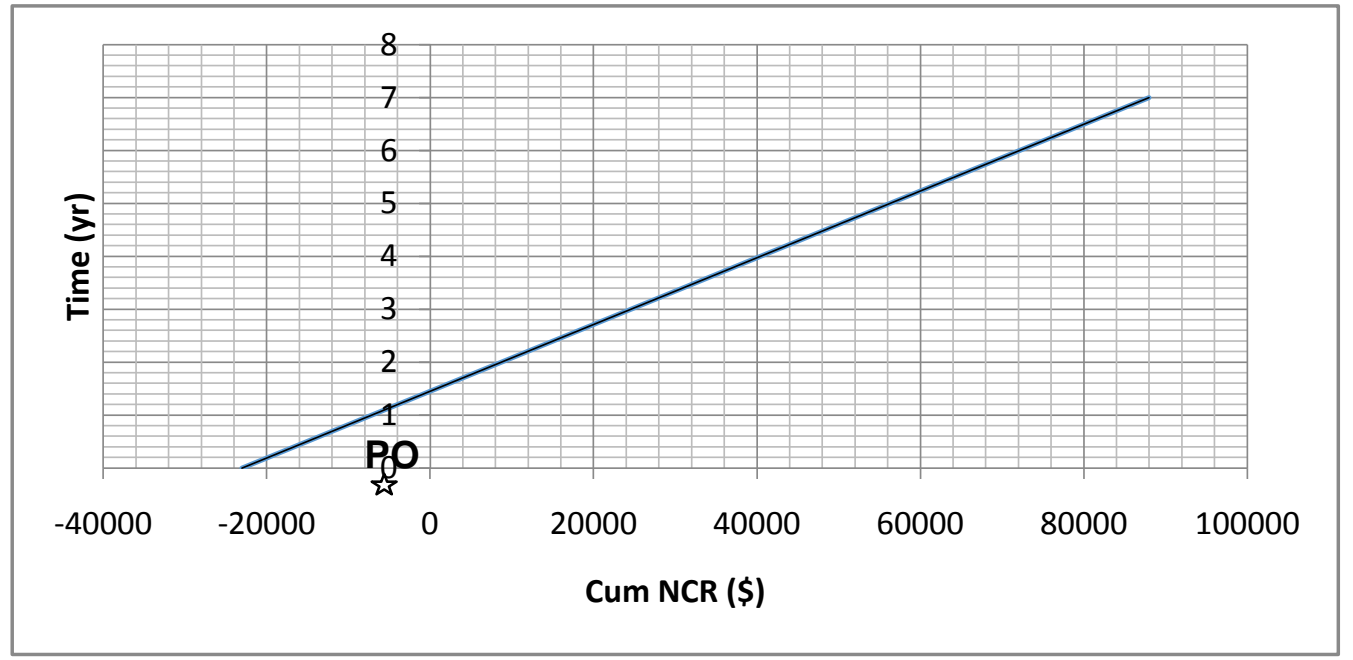

Fig3.2. Plot of Time (yr) against Cum NCR (\$) 


\subsubsection{Effect of CNG Price on the CNG-powered Vehicle Project}

The NPV after 4 years at various CNG prices are as shown in Table 3.7 which was used to plot a chart of NPV (\$) against CNG Price (\$/1) as shown in Fig 3.3. From Fig 3.3, if CNG price goes higher than $\$ 1.18$ per liter ie N190 per liter, then the NPV becomes negative and so it would not be advisable to invest in the CNG-powered vehicle project.

Table3.7. Table of CNG Price $(\$ / l)$ and NPV at $10 \%(\$)$

\begin{tabular}{|l|l|}
\hline CNG Price (\$/l) & NPV @ 10\% (\$) \\
\hline 0.38 & 66130.73 \\
\hline 1.38 & $(17933.8)$ \\
\hline 2.38 & $(101998)$ \\
\hline 3.38 & $(186063)$ \\
\hline 4.38 & $(270127)$ \\
\hline
\end{tabular}

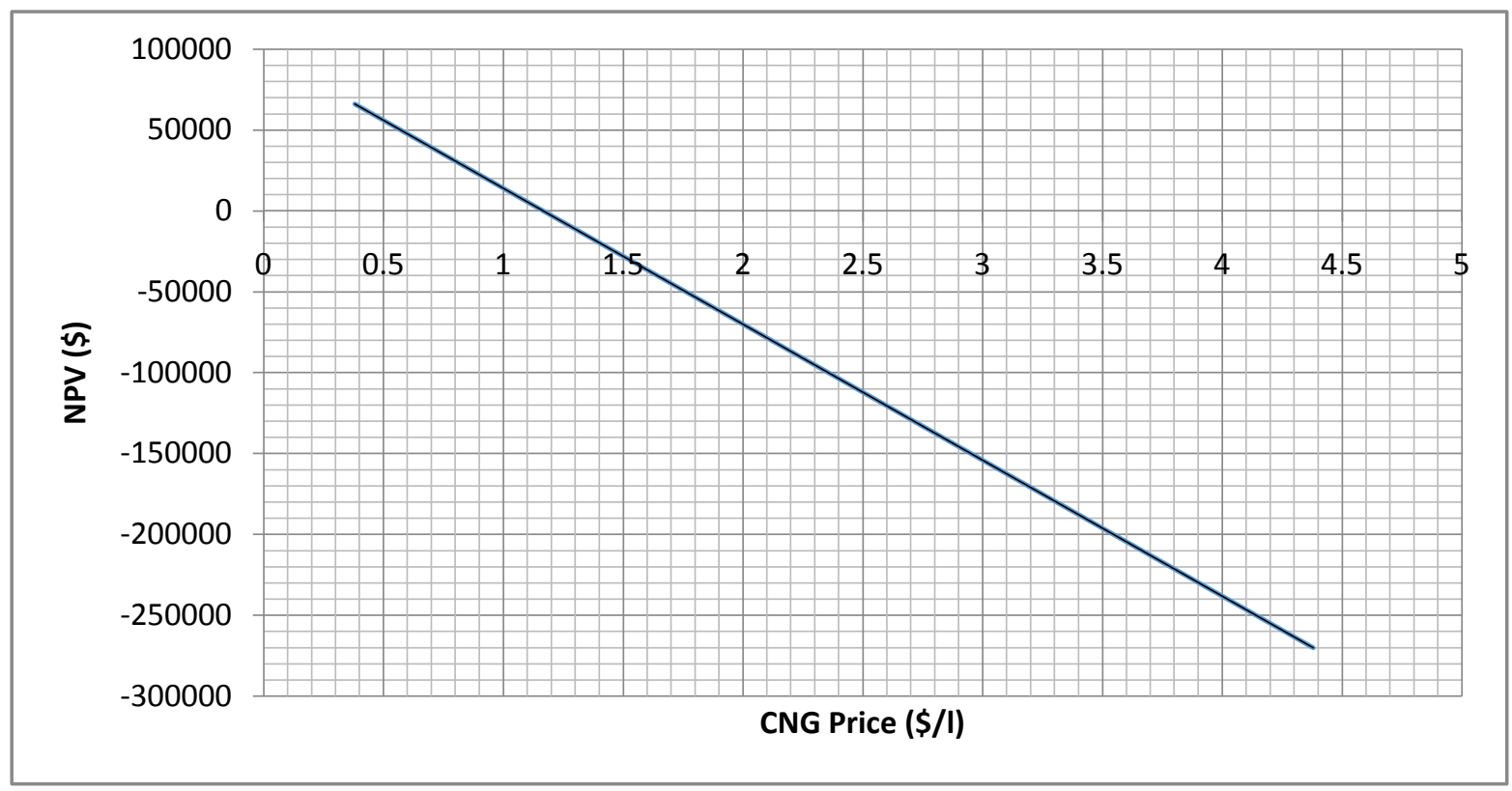

Fig3.3: Plot of $N P V(\$)$ against $C N G$ Price $(\$ / l)$

\subsection{Economic Analysis of Diesel-Powered Vehicle}

\subsubsection{Costs Analyses for Diesel-powered Vehicle}

\subsubsection{Total Capital Cost, $(C)$}

The Total Capital Cost $=$ The Initial Cost of the Diesel-powered Vehicle.

The cost of procuring a diesel-powered vehicle is $\$ 20000=\mathrm{N} 3.22$ million

\subsubsection{Annual Cost, (A)}

\subsection{Fuel Cost, $(F c)$}

According to Watt, (2000), the average kilometer per liter covered by a vehicle running on diesel is $1.04 \mathrm{~km} / 1$. A vehicle that plies $93 \mathrm{~km}$ to and fro within south-east, Nigeria would be covering a distance of $186 \mathrm{~km}$. If 11 of diesel can cover a distance of $1.04 \mathrm{~km}$ then to cover a distance of $186 \mathrm{~km}$ the volume of diesel that would be required is 178.81 . Since the cost of diesel is $\$ 0.5 / 1$, then the cost of 178.81 of diesel is $\$ 89.4$. If the vehicle travels the $93 \mathrm{~km}$ and back 15 times in a month it means that the cost of diesel for the 15 trips in a month is $\$ 1341$. Then the annual cost of fuel would be $\$ 2550 * 12=$ $\$ 16092=\mathrm{N} 2.59$ million

\subsection{Maintenance Cost, $(M c)$}

The cost of maintaining the vehicle, servicing the engine and other parts and repairing the damaged parts would amount to about $\$ 40$ per month which is $\$ 480$ ie N77280 annually.

Annual Cost, $A=F_{c}+M_{c}=\$ 16092+\$ 480=\$ 16572=N 2.67$ million 
The Viability of Converting Diesel Powered Automobiles to Use Compressed Natural Gas as Fuel in Nigeria

\subsection{Revenue Analyses for Diesel-powered Vehicles}

If the money the vehicle yields for one trip of $93 \mathrm{~km}$ and back is $\$ 133$, then Gross Revenue $=\$ 133 *$ $15 * 12=\$ 24000$.

Annual Net Revenue $=\$ 24000-\$ 16572=\$ 7428=$ N1.2 million .

\subsection{NPV and IRR for the Diesel-powered Vehicle Project}

The cash flows in millions of Naira for the diesel-powered vehicle project over the space of 15 years is shown in Table 4.8 below

Table3.8. Cash Flows in millions of Naira for the Diesel-powered Vehicle Project over the space of 15 years

\begin{tabular}{|l|l|l|l|l|l|l|l|}
\hline $\begin{array}{c}\text { Time } \\
(\mathbf{y r})\end{array}$ & $\begin{array}{c}\text { CAPEX } \\
(\mathbf{N M})\end{array}$ & $\begin{array}{c}\text { OPEX } \\
(\mathbf{N M})\end{array}$ & $\begin{array}{c}\text { GROSS REV } \\
(\mathbf{N M})\end{array}$ & $\begin{array}{c}\text { NCR } \\
(\mathbf{N M})\end{array}$ & $\begin{array}{c}\text { CUM NCR } \\
(\mathbf{N M})\end{array}$ & PV @ 5\% (NM) & PV @ 10\% (NM) \\
\hline 0 & 3.22 & 0.00 & 0.00 & $(3.22)$ & $(3.22)$ & $(3.22)$ & $(3.22)$ \\
\hline 1 & 0.00 & 2.67 & 3.86 & 1.19 & $(2.03)$ & 1.14 & 1.09 \\
\hline 2 & 0.00 & 2.67 & 3.86 & 1.19 & $(0.83)$ & 1.08 & 0.99 \\
\hline 3 & 0.00 & 2.67 & 3.86 & 1.19 & 0.36 & 1.03 & 0.90 \\
\hline 4 & 0.00 & 2.67 & 3.86 & 1.19 & 1.56 & 0.98 & 0.82 \\
\hline 5 & 0.00 & 2.67 & 3.86 & 1.19 & 2.75 & 0.94 & 0.74 \\
\hline 6 & 0.00 & 2.67 & 3.86 & 1.19 & 3.94 & 0.89 & 0.67 \\
\hline 7 & 0.00 & 2.67 & 3.86 & 1.19 & 5.14 & 0.85 & 0.61 \\
\hline 8 & 0.00 & 2.67 & 3.86 & 1.19 & 6.33 & 0.81 & 0.56 \\
\hline 9 & 0.00 & 2.67 & 3.86 & 1.19 & 7.53 & 0.77 & 0.51 \\
\hline 10 & 0.00 & 2.67 & 3.86 & 1.19 & 8.72 & 0.73 & 0.46 \\
\hline 11 & 0.00 & 2.67 & 3.86 & 1.19 & 9.91 & 0.70 & 0.42 \\
\hline 12 & 0.00 & 2.67 & 3.86 & 1.19 & 11.11 & 0.66 & 0.38 \\
\hline 13 & 0.00 & 2.67 & 3.86 & 1.19 & 12.30 & 0.63 & 0.35 \\
\hline 14 & 0.00 & 2.67 & 3.86 & 1.19 & 13.50 & 0.60 & 0.31 \\
\hline 15 & 0.00 & 2.67 & 3.86 & 1.19 & 14.69 & 0.57 & 0.29 \\
\hline
\end{tabular}

From Table 3.8, the Net Present Value at an expected rate of return/discount rate (the rate which the capital needed for the project could return if invested in an alternative venture) of 5\% is the sum of the present values in that column for 5\%. The sum of the PVs at 5\% is N9.17 million

The NPV at a discount rate of $10 \%=$ N5.86 million

The project is worth investing on since the NPV in both cases is greater than zero.

The internal rate of return (IRR) on investment of a project is the rate of return that makes the net present value of all cash flows from a particular investment equal to zero. The higher the IRR of a project, the more desirable it is to undertake the project. Table 3.9 is another table generated from Table 3.8 and it shows the cash flows for the project over 4 years. The essence of Table 3.9 is for the generation of the IRR of the project which has to be computed using very short times of undertaking the project. For more accurate values and for taking extreme cases, little number of years, like 2 to 4 years, is used in generating the IRR rather than large number of years. Table 3.9 is shown below:

Table3.9. Cash Flows in millions of Naira for the Diesel-powered Vehicle Project over the space of 4 years

\begin{tabular}{|l|l|l|l|l|l|l|l|}
\hline $\begin{array}{c}\text { Time } \\
(\mathbf{y r})\end{array}$ & $\begin{array}{c}\text { CAPEX } \\
\text { (NM) }\end{array}$ & $\begin{array}{c}\text { OPEX } \\
\text { (NM) }\end{array}$ & $\begin{array}{c}\text { GROSS REV } \\
\text { (NM) }\end{array}$ & $\begin{array}{c}\text { NCR } \\
\text { (NM) }\end{array}$ & $\begin{array}{c}\text { CUM NCR } \\
\text { (NM) }\end{array}$ & $\begin{array}{c}\text { PV @ 5\% } \\
\text { (NM) }\end{array}$ & $\begin{array}{c}\text { PV @ 10\% } \\
\text { (NM) }\end{array}$ \\
\hline 0 & 3.22 & 0.00 & 0.00 & $(3.22)$ & $(3.22)$ & $(3.22)$ & $(3.22)$ \\
\hline 1 & 0.00 & 2.67 & 3.86 & 1.19 & $(2.03)$ & 1.14 & 1.09 \\
\hline 2 & 0.00 & 2.67 & 3.86 & 1.19 & $(0.83)$ & 1.08 & 0.99 \\
\hline 3 & 0.00 & 2.67 & 3.86 & 1.19 & 0.36 & 1.03 & 0.90 \\
\hline 4 & 0.00 & 2.67 & 3.86 & 1.19 & 1.56 & 0.98 & 0.82 \\
\hline
\end{tabular}

Table 3.10 is a table of the net present values for the diesel-powered vehicle project at various discount rates, which was used in generating a plot of NPV against discount rate as shown in Fig 3.4 for the determination of the IRR which is $18 \%$. The $18 \%$ is the discount rate at which the NPV equals zero. 
Anyadiegwu C. I. C. et al.

Table3.10. NPV at various Discount Rates

\begin{tabular}{|l|l|}
\hline Discount Rate (\%) & NPV (NM) \\
\hline 5 & 1.013865 \\
\hline 10 & 0.564819 \\
\hline 15 & 0.188844 \\
\hline 20 & $(0.12905)$ \\
\hline 25 & $(0.40025)$ \\
\hline 30 & $(0.63351)$ \\
\hline 35 & $(0.83564)$ \\
\hline 40 & $(1.01202)$ \\
\hline
\end{tabular}

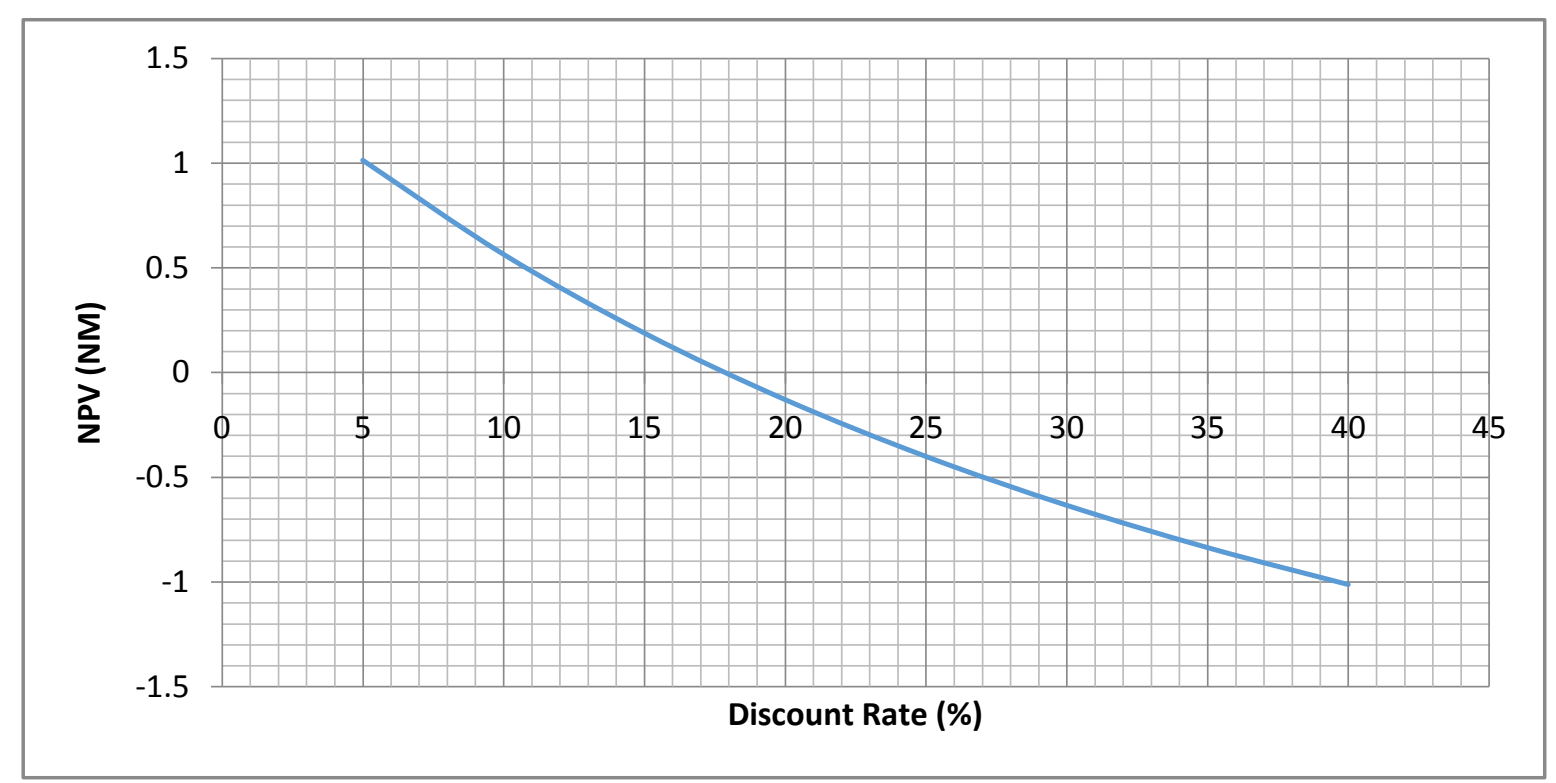

Fig3.4. Plot of NPV against Discount Rate

\subsection{Pay-out (PO) for the Diesel-powered Vehicle Project}

The pay-out for a project refers to the time (years) at which the initial investment on the project is just recovered. It is the time at which cumulative NCR becomes zero.

Table 3.11 shows the cumulative NCR and NCR after 7 years while Fig 3.5 represents the graph of time against cumulative NCR in millions of Naira for the diesel-powered vehicle project.

Table3.11. Cum NCR after 7 years

\begin{tabular}{|l|l|l|}
\hline Time (yr) & NCR (NM) & CUM NCR (NM) \\
\hline 0 & $(3.22)$ & $(3.22)$ \\
\hline 1 & 1.194 & $(2.026)$ \\
\hline 2 & 1.194 & $(0.832)$ \\
\hline 3 & 1.194 & 0.362 \\
\hline 4 & 1.194 & 1.556 \\
\hline 5 & 1.194 & 2.75 \\
\hline 6 & 1.194 & 3.944 \\
\hline 7 & 1.194 & 5.138 \\
\hline
\end{tabular}

From Fig 3.5, cumulative NCR becomes zero between the 2nd and 3rd year. In this research work, 2 and 3 years were used as the initial point (IP) and final point, (FP) respectively.

Applying interpolation:

$(\mathrm{PO}-\mathrm{IP}) /(\mathrm{FP}-\mathrm{IP})=(0-\mathrm{CUM}$ NCR at IP $) /(\mathrm{CUM}$ NCR at FP $-\mathrm{CUM}$ NCR at IP $)$

$(\mathrm{PO}-2 \mathrm{yrs}) /(3 \mathrm{yrs}-2 \mathrm{yrs})=(0-(-0.832)) /(0.362-(-0.832))$

$\mathrm{PO}=2.7 \mathrm{yrs}$ as indicated in Fig. 3.5. 
The Viability of Converting Diesel Powered Automobiles to Use Compressed Natural Gas as Fuel in Nigeria

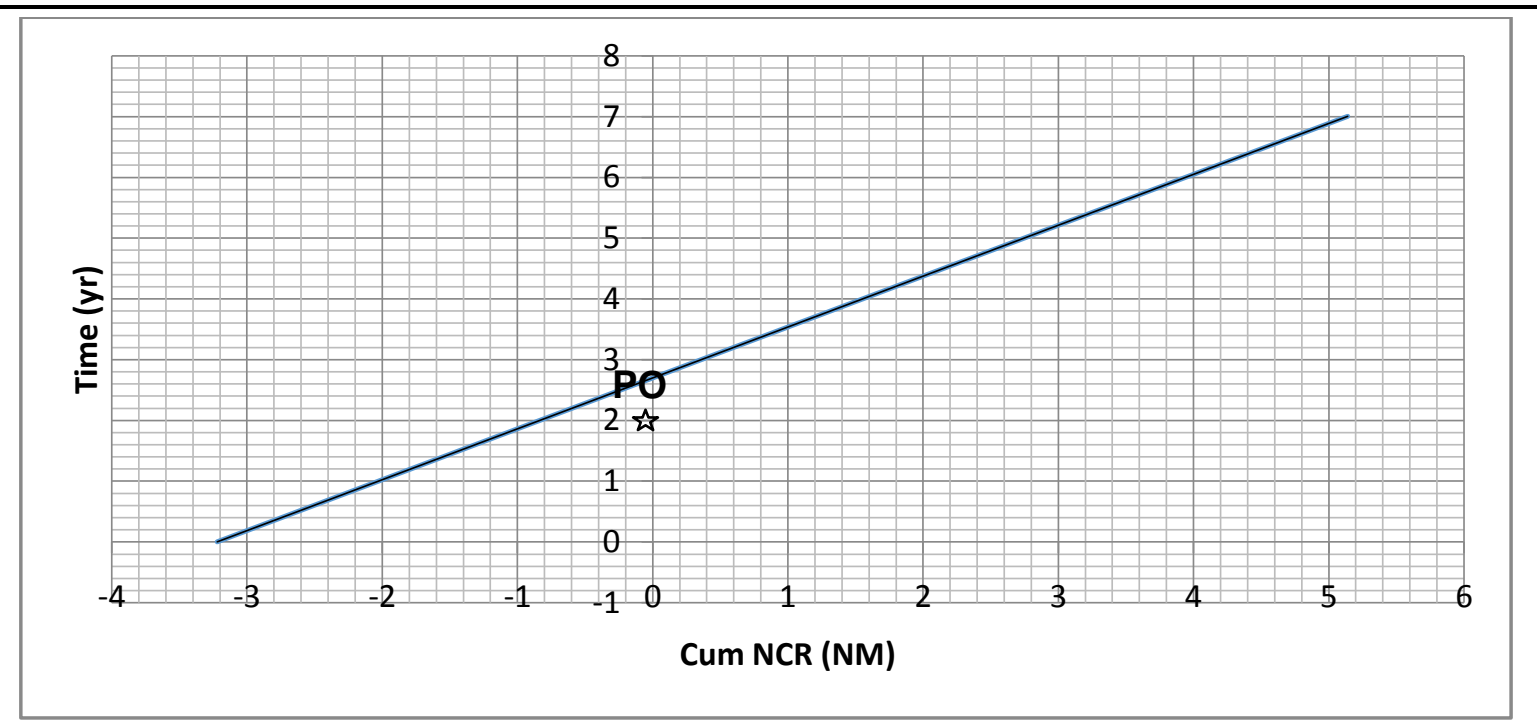

Fig3.5. Plot of Time (yr) against Cum NCR (NM)

\subsection{Effect of Diesel Price on the Diesel-powered Vehicle Project}

The NPV at various diesel prices are as shown in Table 3.12 which was used to plot a chart of NPV $(\mathrm{NM})$ against Diesel Price $(\$ / 1)$ as shown in Fig 3.6. From Fig 3.6, if diesel price goes below $\$ 0.7$ per liter ie N112.7, then the NPV becomes negative and so it would not be advisable to invest in the diesel-powered vehicle project if you are to expect a rate of return of $10 \%$.

Table3.12. Table of Diesel Price $(\$ / l)$ and NPV at $10 \%(N M)$

\begin{tabular}{|l|l|}
\hline Diesel Price (\$/I) & NPV @ 10\% (NM) \\
\hline 0.5 & 4.99 \\
\hline 1.5 & $(16.62)$ \\
\hline 2.5 & $(38.23)$ \\
\hline 3.5 & $(59.83)$ \\
\hline 4.5 & $(81.44)$ \\
\hline
\end{tabular}

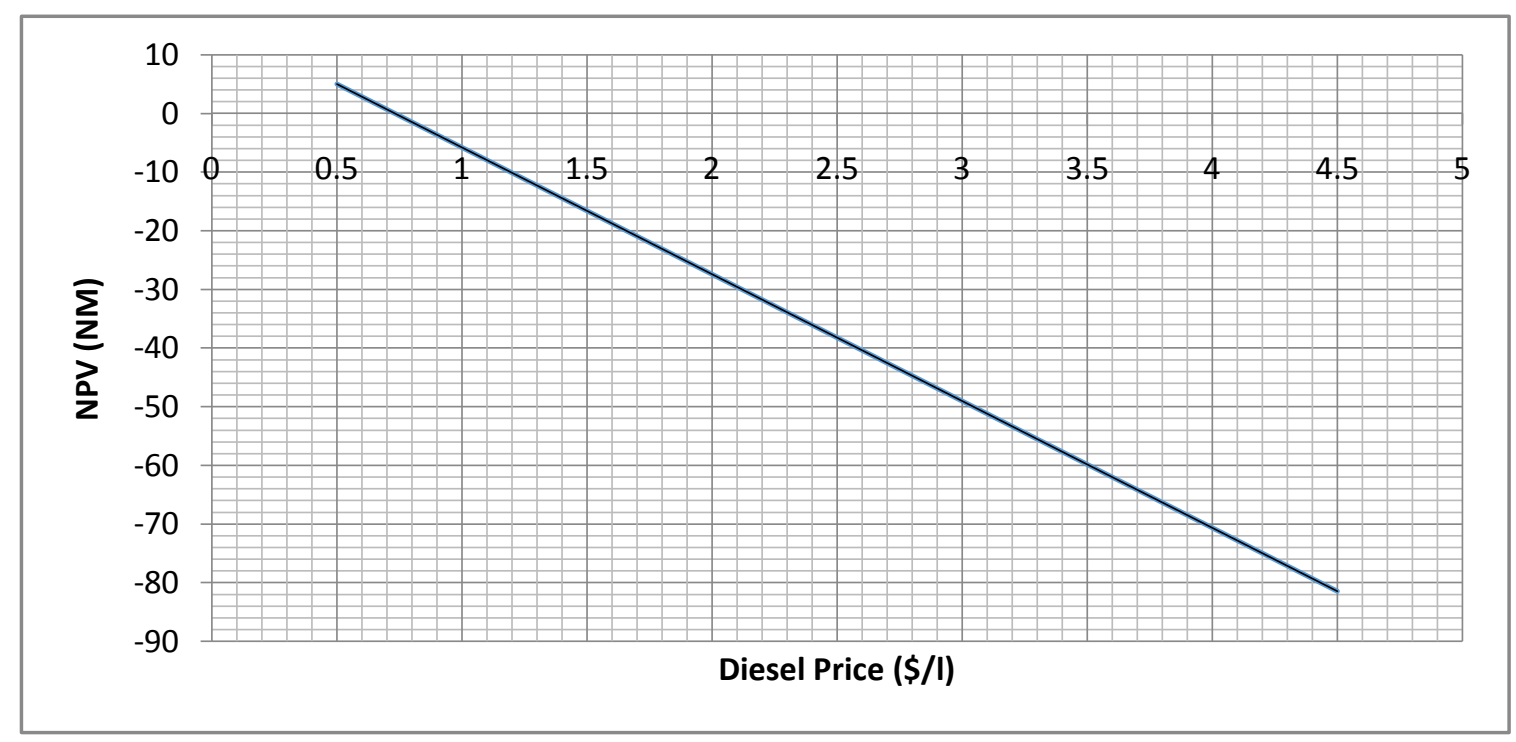

Fig3.6. Plot of NPV $(\$ B)$ against Diesel Price $(\$ / l)$

Table3.13. Summary of the Results of the Analyses

\begin{tabular}{|l|l|l|}
\hline \multicolumn{1}{|c|}{ Economic Parameters } & CNG-powered Vehicle Project & Diesel-powered Vehicle Project \\
\hline Capital Cost, NM & 3.71 & 3.22 \\
\hline Annual Operating Cost, NM & 1.31 & 2.67 \\
\hline Gross Revenue, NM & 3.86 & 3.86 \\
\hline Net Revenue, NM & 2.55 & 1.2 \\
\hline NPV @ 5\%, NM & 22.79 & 9.17 \\
\hline
\end{tabular}


Anyadiegwu C. I. C. et al.

\begin{tabular}{|l|l|l|}
\hline NPV @ 10\%, NM & 15.71 & 5.86 \\
\hline Internal Rate of Return & $24 \%$ at 2years & $18 \%$ at 4 years \\
\hline Pay-out, yr & 1.45 & 2.7 \\
\hline Price Limit for Profitability, N/liter & $\mathrm{N} 190$ & N112.7 \\
\hline
\end{tabular}

\section{Conclusion}

Three profit indicators: NPV, IRR and Pay out were employed in this work for the economic analyses.

The NPV that was obtained for the CNG analysis at different discount rate of 5\% and $10 \%$ were both positive indicating that the project is profitable and acceptable.

The IRR which is the rate of return that makes the NPV of a cash flow equals zero, tells us how efficient a project is. The IRR obtained from the CNG analysis is very much considerable.

The pay- out period obtained from the CNG analysis is a very short period which makes the investment look very attractive and profitable.

From Fig 4.3, it is shown that if the CNG price goes above N190/liter, then the NPV becomes negative and so it would not be advisable to invest in the CNG project

From Fig 4.4, it is shown that if the diesel price goes higher than N112.7/liter, then the NPV becomes negative and so it would not be advisable to invest in the diesel project.

At the end of the analyses, it is proven that it is more economically viable to utilize CNG as vehicular fuel than diesel in Nigeria.

\section{NOMENCLATURE}

$\mathrm{A}=$ Annual Cost

Bcf $=$ Billion cubic foot

$\mathrm{C}=$ Total Capital Cost

CAPEX = Capital Expenditure

$\mathrm{CC}=$ Combustion Chamber

$\mathrm{C}_{\mathrm{CNG}}=\mathrm{CNG}$ Cylinder

$\mathrm{CCoE}=$ Chief Controller of Explosives

$\mathrm{CNG}=$ Compressed natural gas

$\mathrm{COS}_{\mathrm{CNG}}=$ Fuel Change Over Switch

CUM NCR $=$ Cumulative net cash recovery

$\mathrm{EFG}=$ Electric Fuel Gauge

EIA = Energy Information Administration

$\mathrm{ER}=$ Electronic Regulator

$F_{c}=$ Fuel Cost

$\mathrm{FP}=$ Final point

$\mathrm{GJ}=$ Gigajoule

$\mathrm{I}=$ Initial Cost of Vehicle

$\mathrm{IP}=$ initial point

IRR = Internal Rate of Return

$\mathrm{Kg}=$ Kilogram

$\mathrm{KJ}=$ Kilojoule

$\mathrm{Km}=$ Kilometer

$1=$ Liter 
$\mathrm{M}_{\mathrm{c}}=$ Maintenance Cost

$\mathrm{M}_{\mathrm{CNG}}=$ Fuel Mixer

Mscf $=$ Thousand standard cubic foot

$\mathrm{N}=$ Naira

$\mathrm{NCR}=$ Net Cash Recovery

$\mathrm{NM}=$ Million Naira

NPV $=$ Net Present Value

$\mathrm{OEV}=$ On-off Electric Valve

OPEX = Operating Expenditure

$\mathrm{PO}=$ Pay-out

PRDs $=$ Pressure relief devices

PVs $=$ Present Values

$\mathrm{RE}=\mathrm{Re}$-fuelling Electric Valve

$\mathrm{REV}=$ Revenue

$\mathrm{scf}=$ Standard cubic foot

$\mathrm{SV}_{\mathrm{CNG}}=\mathrm{CNG}$ Solenoid Valve

$\mathrm{stb}=$ Stock tank barrel

US DOE $=$ United States Department of Energy

$\$=$ United States Dollar

\section{REFERENCES}

[1] American Gas Association, (1997): AGA Monograph on Underground Gas Storage, Arlington, V.A.

[2] California Energy Commission, (2013): Compressed Natural Gas (CNG) as a Transportation Fuel; Consumer Energy Center; retrieved www.consumerenergycenter.org, July 2013

[3] Go Natural Gas, Inc., (2009): What is CNG? 1644 N. El Camino Real San Clemente, CA 92672; info@gonaturalgas.com; (949) 340-7702

[4] Mahanagar Gas Limited, (2013): Compressed Natural Gas FAQ; E Vision Technologies Retrieved from www.mahanagargas.com.

[5] Nelson Irrigation Corporation, (2013): 800 Series Valve Resource Manual; 848 Airport Road, Walla Walla, WA 99362-2271; Fax: 509-525-7907; USA.

[6] The Engineering Tool Box, (2013): Fuel Gases - Heating Values; Resources, Tools and Basic Information for Engineering and Design of Technical Applications; retrieved www.engineerin gtoolbox. com July 2013.

[7] US DOE, (2013): Compressed Natural Gas Fueling Stations; Alternative Fuels Data Center; Energy Efficiency and Renewable Energy; June 2013.

[8] Watt Glen, (2000): Natural Gas Vehicles Transit Bus Fleets: The Current International Experience; International Association for Natural Gas Vehicles (Inc.) Review Paper; Gas Technology Services Australia

[9] Wikimedia Foundation, Inc., (2013): Compressed Natural Gas; retrieved www.wikipedia.org, June, 2013.

[10] Wikimedia Foundation, Inc., (2013): Net Present Value; retrieved www.wikipedia.org, August, 2013. 